\title{
Implementing a Robotics Curriculum in an Early Childhood Montessori Classroom
}

\author{
Mollie Elkin, Amanda Sullivan, and Marina Umaschi Bers \\ Tufts University, Medford, Massachusetts, USA
}

\author{
Mollie.Elkin@tufts.edu; Amanda.Sullivan@tufts.edu; \\ Marina.Bers@tufts.edu
}

\begin{abstract}
This paper explores how robotics can be used as a new educational tool in a Montessori early education classroom. It presents a case study of one early educator's experience of designing and implementing a robotics curriculum integrated with a social science unit in her mixed-age classroom. This teacher had no prior experience using robotics in the classroom beyond a three-day professional development workshop. The case study was constructed by collecting data from surveys, interviews, and a personal blog written by the teacher documenting her experience. The outcome of this research project is a set of suggested criteria for effectively integrating foundational programming and engineering concepts into Montessori early education, based on the inclusion of Montessori tangibles, the need for teacher confidence, and the encouragement of student collaboration.
\end{abstract}

Keywords: early childhood education, Montessori, robotics, programming, engineering

\section{Introduction}

From doors that open automatically to lights that turn on with a clap, children are growing up in an increasingly technological world. Early childhood education has begun to embrace this change as researchers and policymakers have pushed for an increased focus on STEM (science, technology, engineering, and mathematics) education in early childhood classrooms (Barron et al., 2011; Gelman \& Breneman, 2004; National Association for the Education of Young Children [NAEYC] \& Fred Rogers Center, 2012; Sesame Workshop, 2009; U.S. Department of Education, 2010). Research has highlighted the importance of exposing young children to STEM early on to ensure that they avoid stereotypes and other obstacles to enter these fields in later years (Madill et al., 2007; Markert, 1996; Metz, 2007; Steele, 1997).

As part of this push, new technology learning standards and best practices for integrating tech-

Material published as part of this publication, either on-line or in print, is copyrighted by the Informing Science Institute. Permission to make digital or paper copy of part or all of these works for personal or classroom use is granted without fee provided that the copies are not made or distributed for profit or commercial advantage AND that copies 1) bear this notice in full and 2) give the full citation on the first page. It is permissible to abstract these works so long as credit is given. To copy in all other cases or to republish or to post on a server or to redistribute to lists requires specific permission and payment of a fee. Contact Publisher@InformingScience.org to request redistribution permission. nology into early learning classrooms have been developed. Teachers from a variety of different backgrounds have become interested in finding ways to incorporate new technology into their curricula (Barron et al., 2011; International Society for Technology in Education (ISTE), 2007; NAEYC \& Fred Rogers Center, 2012; U.S. Department of Education, 2010). However, for teachers from a Montessori perspective,

Editor: Jane Nash

Submitted September 20, 2014; Revised December 19; accepted December 31, 2014 
using digital technologies may seem foreign and out of place alongside traditional Montessori manipulatives like enameled metal, wicker, and fabric (American Montessori Society, 2013b). In the modern Montessori classroom, the question of where and how new technologies fit in has become a growing matter of debate.

The goal of the case study presented in this paper is to develop an effective approach for integrating foundational programming and engineering concepts into Montessori early education. This study follows one lower elementary Montessori teacher and documents her experience developing and implementing a robotics curriculum for the first time while integrating STEM concepts with social science. This paper will present the synthesized approach as well as provide future directions for integrating robotics with the Montessori principles. This case study is constructed using data resulting from surveys, interviews, and the teacher's personal blog.

\section{Literature Review}

\section{Montessori Education}

The classroom presented in this study follows a traditional Montessori approach to education. Created by Dr. Maria Montessori over a century ago, the Montessori teaching method focuses on a child's natural inclination to learn (American Montessori Society, 2013b; Montessori, 1912). In this environment, a teacher's role is to provide developmentally-appropriate materials and give students the freedom to explore their personal interests. Teachers do not direct learning but respect children's efforts towards independent mastery (American Montessori Society, 2013b; Montessori, 1912). Montessori schools in the United States, such as the one described in this case study, are typically private and tend to serve children whose parents can afford private tuition (Lillard, 2010).

One of the defining features of the Montessori approach is that students stay in their respective classrooms for multiple years, giving them the opportunity to form a close relationship with both their fellow students and their teacher (American Montessori Society, 2013b; Lillard, 2010; Montessori, 1912). According to Montessori (1912), children's natural tendencies unfold when they are in these specially designed multi-age environments. In this type of setting, collaboration plays a large role in the classroom to foster a sense of community amongst students.

Montessori classrooms are also known for the use of "beautiful objects" and manipulatives such as glass beads, metal, and wicker (American Montessori Society, 2013b; Lillard, 2010). These materials are often used for counting, forming words, or playing games. This type of object-based learning has been associated with better learning outcomes and fostering cognitive development skills in young children (Glenberg, Gutierrez, Levin, Japuntich, \& Kaschak, 2004; Montie, Xiang, $\&$ Schweinhart, 2006). Montessori teachers demonstrate handling these fragile materials slowly and respectfully so that children naturally sense something magical about learning with these objects (American Montessori Society, 2013b).

For many teachers, incorporating new technologies amongst traditional Montessori materials may feel out of place or unaligned with the Montessori tradition. However, in the American Montessori Society's (2013a) most recent position statement on technology, new technologies were encouraged in order to foster digital literacy and $21^{\text {st }}$ century skills. At the same time, the statement cautioned that technology "must be carefully thought out and integrated so that it complements, but does not replace any part of the Montessori approach or curriculum." Furthermore, any new technology used in the Montessori classroom must be continually reviewed for its developmental appropriateness (American Montessori Society, 2013a). Incorporating technology into Montessori classrooms has stirred a discussion among parents, educators, and policy makers. For example, Schneider (2012) supports technology integration and describes intersections between Mon- 
tessori education and digital learning. She writes that "both high-quality digital learning and Montessori prioritize the personalization of learning and create systems that allow for customization of content and instruction" (Schneider, 2012).

\section{Robotics in Early Childhood Education}

From an economic and a developmental standpoint, educational interventions that begin in early childhood are associated with longer-lasting effects than interventions that begin later in childhood (Cunha \& Heckman, 2007; Reynolds, Temple, Ou, Arteaga, \& White, 2011; A. Sullivan, Kazakoff, \& Bers, 2013). Research shows that children who are exposed to STEM and computer programming at an early age demonstrate fewer gender-based stereotypes when choosing STEM careers (Metz, 2007; Steele, 1997) and fewer obstacles entering these academic fields (Madill et al., 2007; Markert, 1996). One way to expose young children to STEM in a developmentallyappropriate way is through the use of robotic manipulatives. Robotics is an engaging way to foster interdisciplinary explorations and personal connections through the use of technology (Bers, 2008).

In the Montessori early childhood classroom, the use of robotic manipulatives is consistent with other types of Montessori materials. Robotic manipulatives allow children to participate in creative explorations, develop fine motor skills and hand-eye coordination, and engage in collaboration and teamwork (Bers, 2008, 2010; K. Lee, Sullivan, \& Bers, 2013). Just like traditional Montessori manipulatives, such as pattern blocks and beads, educational robotics kits can help children develop a stronger understanding of mathematical concepts such as number, size, and shape (Bers, 2012; Resnick et al., 1998).

Robotics also provides a way to engage young children in problem solving and "debugging" as they build and create. Debugging, or trouble-shooting, is a form of problem solving used in the fields of engineering and computer science (Bers, Flannery, Kazakoff, \& Sullivan, 2014). To debug a problem, the child must first recognize that something is not working either with the robotic parts or the accompanying computer program. When debugging a robotics problem, there is typically not one "right" answer, but a variety of ways for children to creatively solve a problem.

The steps of the debugging process are a critical component of the Engineering Design Process, which refers to the cyclical or iterative process engineers use to design an artifact in order to meet a need (Massachusetts Department of Education, 2006). Teaching robotics using the Engineering Design Process establishes a learning environment where failure, as opposed to immediate success, is expected and even necessary for learning. With the Engineering Design Process, children are not expected to "get it right" the first time, but to engage with different problem solving strategies (Bers et al., 2014). This provides a unique opportunity for focusing on the learning process, as opposed to learning outcomes.

While the majority of educational work on robotics and engineering has focused on middle and high school students, recent work has shown that the field of robotics holds special potential for early childhood classrooms (Bers, 2008; Bers \& Horn, 2010; Kazakoff \& Bers, 2012). Research shows that children as young as four years old can successfully build and program simple robotics projects while learning a range of engineering and computer science concepts in the process, and that teachers can successfully integrate robotics with other curricular areas (Bers, Ponte, Juelich, Viera, \& Schenker, 2002; Cejka, Rogers, \& Portsmore, 2006; Perlman, 1976; A. Sullivan, Kazakoff, \& Bers, 2013).

\section{Programming in Early Education}

Robotics involves making physical artifacts that come to "life" by programming their behaviors. When children program robots, they sequence commands for the robot to act out (Kazakoff \& 
Bers, 2012; Kazakoff, Sullivan, \& Bers, 2013). Sequencing skills are foundational for early math, literacy, and planning (Zelazo, Carter, Reznick, \& Frye, 1997). Prior research with robotics and programming curriculum has shown repeated, significant improvements in sequencing skills for children in kindergarten and prekindergarten classrooms (Kazakoff \& Bers, 2012; Kazakoff et al., 2013).

Computer programming promotes sequencing skills while fostering "computational thinking". This term encompasses a broad and somewhat debated range of analytic and problem-solving skills, dispositions, habits, and approaches used in computer science (Barr \& Stephenson, 2011; I. Lee et al., 2011). The foundation for computational thinking is abstraction. Abstracting concepts from cases and evaluating and selecting the "right" abstraction are critical parts of computer programming (Bers, 2010; Wing, 2006).

\section{Integrating Robotics into Montessori Education}

Prior research on engineering and robotics has demonstrated that young children can experience a range of cognitive and social benefits when these materials are introduced in developmentally appropriate ways (Bers, 2008; Bers \& Horn, 2010; Kazakoff \& Bers, 2012). Despite the fact that technology manipulatives can fit nicely into the Montessori classroom, there is very little research on integrating technology into Montessori early childhood education. This study will connect the body of research on early childhood robotics with the research on Montessori early education in order to identify guidelines for effectively integrating robotic manipulatives into a multi-age Montessori classroom.

\section{Method}

This case study is constructed using a mixed methods approach in order to evaluate how successful an early childhood teacher is in integrating robotics in her Montessori classroom. Qualitative and quantitative measures are employed including surveys, interviews, and blogs. To evaluate the success of this approach, the following criteria are used: the extent to which the robotics kit emulates Montessori tangibles, the teacher's comfort integrating robotics into her curriculum, and the collaboration of students throughout the curriculum. These criteria were selected to reflect both the Montessori principles as well as the fundamental engineering and robotics concepts.

\section{Participant}

This study follows an early childhood educator named Diana throughout her first year implementing a robotics curriculum in her classroom. She received her Bachelors of Arts in Art History from Oberlin College and then continued on to obtain her American Montessori Society 6-9 training through the Center for Montessori Education. After completing her internship at a Montessori school in the Boston, MA area, she stayed on to become a permanent teacher there.

Diana teaches lower elementary school students, first through third grade, at an independent, coeducational Montessori day school that serves toddlers through grade 8. Currently, there are 236 students and 55 faculty members. Each classroom is mixed-age, following the Montessori core principles. Students attend from 28 surrounding towns, and $48 \%$ of the students are of color.

During this study, Diana's classroom had 19 students; 6 students were in first grade, 8 students were in second grade, and 5 students were in third grade. Of those students, five students had previous experience working with the robotics kit used in this study, LEGO ${ }^{\circledR}$ WeDo ${ }^{\mathrm{TM}}$ kits. $\mathrm{WeDo}^{\mathrm{TM}}$ is a robotics kit designed for children over 7 years old that allows building functional robots with LEGOs, motors, gears, and sensors. Once a robot is built, children connect their robots to the computer to program their movements using the accompanying $\mathrm{WeDo}^{\mathrm{TM}}$ software. This kit will be described in more detail in later sections of this paper. 


\section{Procedure}

Before teaching her robotics curriculum, Diana participated in a three day professional development institute at Tufts University with 29 other early childhood teachers from across the country (Bers, Seddighin, \& Sullivan, 2013). During the institute, teachers learned about the engineering and programming aspects of robotics by using the commercially available LEGO ${ }^{\circledR}$ WeDo ${ }^{\mathrm{TM}}$ robotics construction set and the accompanying software. As a final project during the institute, each participating teacher designed a robotics-based curricular unit to later implement in his or her classroom. At the end of the institute, teachers were given all of the necessary robotic materials they would need to implement a curriculum on their own. Additionally, teachers were able to access teaching materials, peer support, and curriculum development materials by using an online community. Teachers were then asked to document their experiences throughout every step of curriculum implementation.

\section{Surveys}

After attending the summer institute, Diana completed two sets of surveys. All surveys were conducted online and completed before and after curriculum implementation. The first survey, the Curriculum Design survey, looked at Diana's planned curriculum and how it was executed. On the pre-survey, Diana answered questions about what core curriculum subjects she intended to teach using robotics, and how she planned to integrate this curriculum into her regular classroom schedule. All questions were open-ended and able to be answered in a few words or a full paragraph. The post-survey included the pre-survey and additional reflection questions.

The second survey aimed to measured Diana's robotics knowledge and attitude and was adapted from a variety of the technical knowledge surveys and instruments used in the field (i.e., Schmidt et al., 2009; F. R. Sullivan \& Moriatry, 2009). The questions addressed the following categories: robotics knowledge, teaching style, teaching with robotics, robotic technical skills, and technology self-efficacy. A 5-point Likert scale was used for answering the 63 questions on each survey (pre and post). For all questions, she was given a series of statements to respond to with the following options: (1) Strongly Disagree, (2) Disagree, (3) Neither Agree/Nor Disagree, (4) Agree, and (5) Strongly Agree. This paper focuses on the categories of robotics knowledge, teaching with robotics, and technology self-efficacy. An example question from each of the three categories addressed in this paper can be found in Table 1 .

Table 1: Questions from Robotics Knowledge Survey from both Pre- and Post-Surveys

\begin{tabular}{|l|l|}
\hline Category & Sample Question \\
\hline Robotics Knowledge & I know how a robot is given instructions. \\
\hline Teaching with Robotics & $\begin{array}{l}\text { I know how to teach robotics in a developmen- } \\
\text { tally appropriate way for young children. }\end{array}$ \\
\hline Technology Self-Efficacy & $\begin{array}{l}\text { Ifeel confident that I can successfully teach } \\
\text { relevant subject content with appropriate use of } \\
\text { technology. }\end{array}$ \\
\hline
\end{tabular}

\section{Blogs}

Diana wrote a blog entry immediately following each robotic session that she taught in her classroom. Blog entries were submitted through a Google form, and responses were compiled into a Google spreadsheet. In each entry, Diana answered the following prompts: what happened, what was a success story, what were the challenges, what big ideas were learned, and what pedagogical tool and strategies were most helpful. There was also space for her to include any additional in- 
formation she wished to share. In total, Diana completed nine blog entries over the course of two months.

\section{Interviews}

Diana was interviewed by researchers at Tufts University after teaching two robotic sessions. While the head researcher had a set of guiding questions, the interview was also guided by how Diana responded. In addition to the formal interview, Diana provided further information as requested.

\section{Classroom materials}

Diana's curriculum used the LEGO ${ }^{\circledR}$ Education WeDo ${ }^{\mathrm{TM}}$ Robotics Construction Set. This is a robotics kit designed for children 8 to 11 years old that allows children to build LEGO ${ }^{\circ}$ robotics that feature working motors and sensors (see Figure 1). The construction kit contains more than 150 elements including a motor, tilt sensor, motion sensor, a LEGO ${ }^{\circledR}$ USB hub, gears, and a variety of LEGO ${ }^{\circledR}$ bricks. Once a robot is built, children connect their robots to the computer using the USB hub and create programs using the accompanying $\mathrm{WeDo}^{\mathrm{TM}}$ software. This software is an icon-based drag-and-drop software, powered by LabVIEW ${ }^{\mathrm{TM}}$, and the on-screen programming icons fit together like puzzle pieces (see Figure 2).

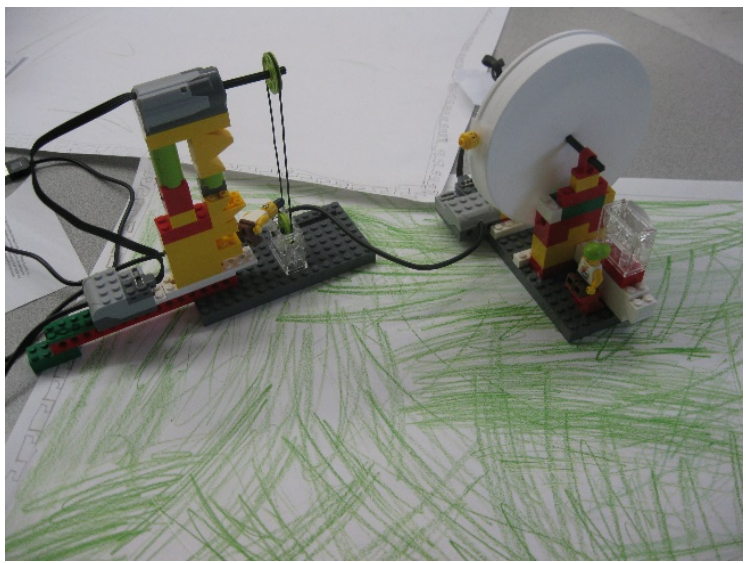

Figure 1: Example of WeDo ${ }^{\mathrm{TM}}$ robot

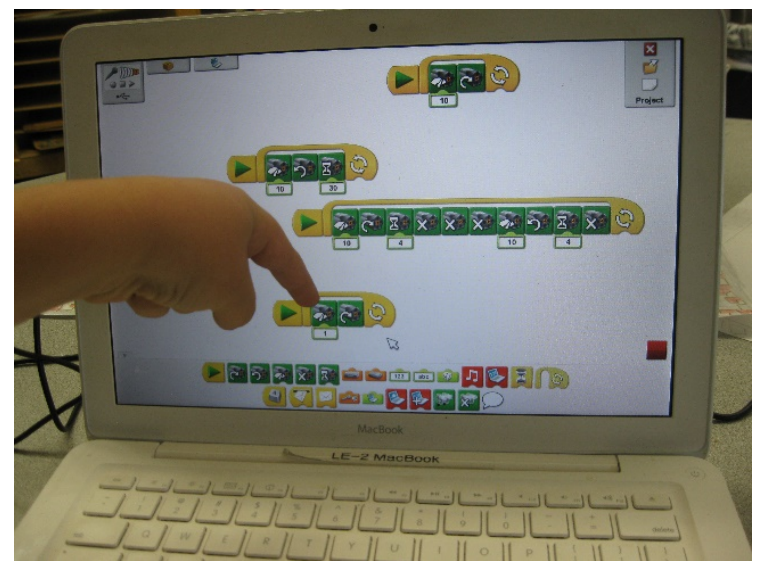

Figure 2: Example program in the LEGO® ${ }^{\circledR}$ WeDo $^{\text {TM }}$ software

\section{Curriculum Theme}

Diana's curriculum, "The Playground: Facilitating a Multi-faceted Design Process through Robotics \& Programming," was an adaptation of a curriculum created by the DevTech Research Group at Tufts University. This six lesson curriculum focused on teaching the Engineering Design Process, the parts of a robot, foundational programming, and sensors using the theme of simple machines. Diana adapted the curriculum to make it work for Ancient Greece, a topic that she had already been teaching for many years. While there is no direct connection between Ancient Greece and robotics, Diana felt it would be most effective to integrate robotics with a previously designed curriculum that she was comfortable teaching.

Each lesson ranged in length from about an hour to over three and a half hours and was subdivided into three sections: warm-up activities, the main activity, and a concluding activity (see Table 2). 
Table 2. Ancient Greece Robotics Curriculum Outline

\begin{tabular}{|c|c|c|c|}
\hline Activity Title & Warm-Up Activity & Main Activity & Concluding Activity \\
\hline $\begin{array}{l}\text { 1: The Engineering } \\
\text { Design Process }\end{array}$ & $\begin{array}{l}\text { Visit a playground and } \\
\text { observe structures }\end{array}$ & $\begin{array}{l}\text { Build a non-robotic } \\
\text { structures where at } \\
\text { least one toy person } \\
\text { can "use" the struc- } \\
\text { ture }\end{array}$ & $\begin{array}{l}\text { Community Meeting to } \\
\text { talk about the successes } \\
\text { and frustrations of the } \\
\text { lesson }\end{array}$ \\
\hline 2: What is a Robot? & $\begin{array}{l}\text { Community Meeting to } \\
\text { talk about what is a ro- } \\
\text { bot }\end{array}$ & $\begin{array}{l}\text { Build a WeDoTM ro- } \\
\text { bot using LEGOs }{ }^{\mathrm{T}} \text {, } \\
\text { motors, and hubs }\end{array}$ & $\begin{array}{l}\text { Play "Programming } \\
\text { Charades" to learn } \\
\text { about different icons } \\
\text { from the WeDo } \\
\text { software }\end{array}$ \\
\hline $\begin{array}{l}\text { 3: What is a Pro- } \\
\text { gram? }\end{array}$ & $\begin{array}{l}\text { Play "Simon Says" with } \\
\text { the WeDo }{ }^{\mathrm{TM}} \text { program- } \\
\text { ming icons }\end{array}$ & $\begin{array}{l}\text { Create and program a } \\
\text { robotic seesaw to tilt } \\
\text { back and forth }\end{array}$ & $\begin{array}{l}\text { Free-play with robotics } \\
\text { materials }\end{array}$ \\
\hline $\begin{array}{l}\text { 4: What are Re- } \\
\text { peats? }\end{array}$ & $\begin{array}{l}\text { Learn and sing the song } \\
\text { "Michael Finnegan" }\end{array}$ & $\begin{array}{l}\text { Use repeats to make } \\
\text { seesaws tilt from left } \\
\text { to right } 5 \text { times }\end{array}$ & $\begin{array}{l}\text { Community Meeting to } \\
\text { debrief about activity }\end{array}$ \\
\hline $\begin{array}{l}\text { 5: What are Sen- } \\
\text { sors? }\end{array}$ & $\begin{array}{l}\text { Guided activity to talk } \\
\text { about the five human } \\
\text { senses }\end{array}$ & $\begin{array}{l}\text { Add motion and tilt } \\
\text { sensors to robotics } \\
\text { built in previous ac- } \\
\text { tivity }\end{array}$ & $\begin{array}{l}\text { Work in group to create } \\
\text { a dramatic representa- } \\
\text { tion of how humans } \\
\text { sense the world versus } \\
\text { how robots sense the } \\
\text { world }\end{array}$ \\
\hline $\begin{array}{l}\text { Culminating Project: } \\
\text { Ancient Robotic } \\
\text { Playground }\end{array}$ & $\begin{array}{l}\text { Work in small groups to } \\
\text { plan for final project }\end{array}$ & $\begin{array}{l}\text { Create and program } \\
\text { robotic playground } \\
\text { structures using the } \\
\text { LEGO® WeDo }{ }^{\mathrm{TM}} \\
\text { kits and accompany- } \\
\text { ing software; decorate } \\
\text { robots using the Crea- } \\
\text { tive Basket of Joy }\end{array}$ & $\begin{array}{l}\text { Open House with par- } \\
\text { ents, administration, } \\
\text { other students }\end{array}$ \\
\hline
\end{tabular}

\section{Montessori Features}

Diana adjusted the lessons to incorporate core Montessori principles that she was already using in her classroom. In particular, Diana focused on collaboration and using multiple modes to teach the engineering and robotics content. Diana's students recorded courteous acts that they witnessed throughout the unit on a colorful paper chain called the Kindness Chain. This encouraged students to work together and take notice when others were helpful. She also incorporated community meetings, an opportunity for students to discuss their thoughts on daily activity, share new ideas, and give feedback to one another. Diana expressed that in her classroom it is important to 
"talk about what happened, what worked, what didn't work." Additionally, students had access to the Creative Basket of Joy, a bin full of recyclable materials that they could incorporate into their robotic projects to make them personally meaningful.

In addition to teaching the fundamental engineering and programming concepts, Diana planned to incorporate other curricular areas, such as the arts and mathematics. She used different methods of teaching the robotic concepts in order to cater for the different learning styles of her students. For example, during her Lesson 1, Diana compared the Engineering Design Process to students "prior knowledge from similar processes in art, music, research, scientific observation, math, and writing." Additionally, Diana incorporated games, music, and books into almost every lesson. For example, Diana planned to play "Programming Charades." Modeled off of the original game, one student would silently act out a series of programming commands from the LEGO ${ }^{\circledR} \mathrm{WeDo}^{\mathrm{TM}}$ software, and the class would guess the correct commands.

\section{Results}

\section{Curriculum Implementation}

In order to evaluate the criteria of emulating Montessori manipulatives and collaboration between students, Diana's curriculum implementation, as well as her Curriculum Design pre and post surveys, was analyzed. Overall, the robotics curriculum involved nine sessions over the course of two months. Each warm-up and concluding activities lasted approximately 20 minutes, and each main activity lasted about 1 hour. Diana designated regular meeting times each week to teach her robotics curriculum, and she allotted extra time for the final project. Of the nine sessions, six of them were focused on teaching content, while three of them were devoted to students working on their final project. In addition to these sessions, other students, parents, and teachers were invited to attend an open house where the class shared its work.

While Diana kept the same overall theme of Ancient Greece, she adjusted the pace and content of the lessons, spreading each out over multiple part of one or more days. Diana's Curriculum Design pre- and post-surveys indicated that she adjusted her robotics curriculum "as necessary- especially if a teaching concept needed more time." Her revised curriculum is as follows:

\section{Activity 1: Engineering design process}

The first lesson of the curriculum, divided into three sessions, was devoted to introducing the simple machines, how inventions from Ancient Greece are still applicable today, and learning the Engineering Design Process. Rather than visiting a playground for the warm-up activity, Diana showed pictures of Ancient Greece and artifacts to her students to remind them about the influence that Greece still has today. Then, students thoughtfully discussed questions such as, "What are the kinds of things that we invent in class?" in which they responded with answers such as "stories" and "friendship." This discussion was continued a week later to encompass influential inventors and inventions such as the incline plane and lever. Diana described these classroom meetings as having a lot of energy, particularly when students brought in knowledge from previous lessons. For example, one student brought up the book "The Way Things Work" by David Macaulay to explain his understanding of levers. To Diana's surprise, this book resonated with many other students, and the book quickly sparked new conversation.

The main activity occurred about a week later when Diana introduced the engineering challenge of building a sturdy lever or inclined plane. To make the task more realistic, Diana told students that the sturdy structure needed to be used by a toy pig. Students could use recyclable materials such as corrugated cardboard, cardstock, tubes, and packing peanuts to create their projects. Working in small groups, students brainstormed and then created their non-robotic levers using 
recyclable materials from the Creative Basket of Joy. After demonstrating initial ideas to the class, students went back to their projects and begin improving their structures. Diana described this day as successful, especially because "[they had] a group of collaborators already. This work [came] naturally to them." These non-robotic structures became the models for the robotic structures in Activity 2.

\section{Activity 2: What is a robot?}

During the fourth session, Diana introduced the electronic components of robotics to her students. For the warm-up activity, the class had a conversation about different types of robots they have encountered or know about, and what makes something a robot. Students discussed items such as microwaves and the Mars Land Rover, debating whether or not each had qualities of a robot. At the end of the lesson, Diana divided the class into five groups of about four students each. In these groups, the class explored the robotic elements of the WeDo ${ }^{\mathrm{TM}} \mathrm{kits}$, for the first time, through the creation of levers. Diana commented that "we had so much success with [the] previous lesson...we weren't prepared for the difficulty they faced when handed a whole LEGO ${ }^{\circledR}$ Education kit." While some students struggled with this engineering challenge, Diana was impressed by the originality behind each group's solution to create a sturdy structure. Diana noted that students were already used to seeing others come up with alternative solutions while using the same materials.

\section{Activity 3: What is a program?}

Building on the previous activity, students had the opportunity to add a program to their alreadydesigned robotic lever. For a warm-up activity, the class reviewed the Engineering Design Process by analyzing how a particular toy was designed. Also, as part of this discussion, they addressed the topic of conflict resolution and brainstormed ways to ensure that everyone was included during robotics. As a class, they decided that groups would work best, so they broke into small groups for the main activity.

In five groups, students created programs to make their robotic levers tilt from one side to another. Diana asked the students with previous LEGO ${ }^{\circledR} \mathrm{WeDo}^{\mathrm{TM}}$ experience to lead each group, but she soon encountered some challenges. In particular, one of the group leaders "wanted to work alone and did not accept help or ideas from others." While at first sharing was a challenge for the students, the lesson quickly became a learning opportunity about conflict resolution. Diana commented in her post- survey that "because the classroom is already set up for students to show what they know and help others in the process, students took pride in demonstrating their skills." Throughout this lesson, Diana noticed how students were consistently testing and improving their programs. From her point of view, "the success was in seeing them work through difficulty."

\section{Culminating project: Ancient robotic playground}

Students devoted three sessions to building and programming their robots to create an Ancient Greek Playground. To begin, students reviewed the Engineering Design Process, inventions from Ancient Greece, and the different programming actions in the WeDo ${ }^{\mathrm{TM}}$ software. Then, in four groups, children began brainstorming robotic structure ideas and testing out possible programs. Diana intentionally put at least one student with prior LEGO ${ }^{\circledR} \mathrm{WeDo}^{\mathrm{TM}}$ experience in each group.

Children used both LEGO ${ }^{\circledR}$ parts and arts and crafts materials from the Creative Basket of Joy to create their playground structures. In the end the final projects were as follows: a pulley swing, a labyrinth with a spinning trophy (see Figure 3), a ferris (water) wheel and a pulley. 


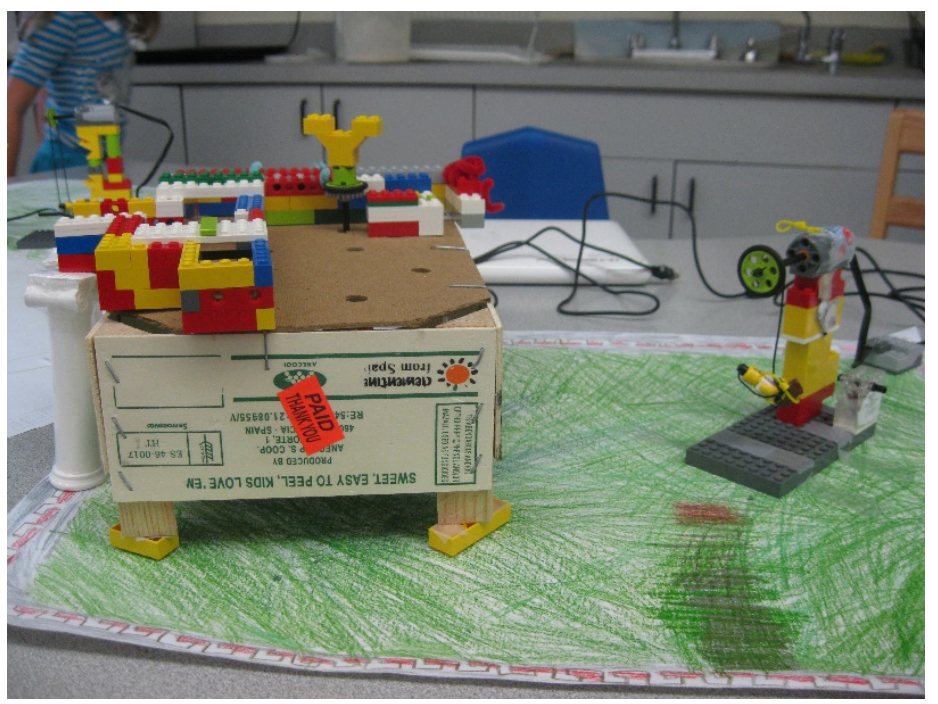

Figure 3: Example final project of the labyrinth with a spinning trophy

After the completion of their projects, students had the opportunity to participate in an open house, where they showed adults their robotic creations, explained the Engineering Design Process, and talked about their individual roles in the projects. Diana explained, "Letting the students speak for themselves about their work and show what makes them proud brought joy to our community. Administrators and other faculty love to connect with students and this gave them an opportunity beyond daily interactions." Students took turns showing their programs and tweaking them if they ran into problems. While the final creations were different than Diana expected, "the theme gave focus to the task and the students' vision, of course, was different but equally wonderful."

\section{Robotics Knowledge Survey}

In order to evaluate how well Diana met the criteria of teacher confidence, her responses on the Robotics Knowledge pre-and-post surveys were analyzed. Diana used a 1-5 Likert Scale (with $1=$ Strongly Disagrees and 5=Strongly Agrees) to describe her robotics knowledge, teaching style, confidence of teaching with robotics, robotic technical skills, and technology self-efficacy. This paper focused on the categories of robotics knowledge, teaching with robotics, and technology self-efficacy because they are most relevant to Diana's experience. Each of these categories contained five to ten questions addressing similar concepts. Diana's mean score for each category of questions was calculated and analyzed. Quotes from her blog and interview are included to illustrate trends found in the quantitative data.

In the category of robotics knowledge, Diana self-reported an increase in her understanding of the parts and function of a robot, as well as the stages and application of the Engineering Design Process, after implementing a robotics curriculum in her classroom. She answered every question in this category during her pre-test with a 4 (Agree), while she answered every question on her post-test with a 5 (Strongly Agree). This is the category in which her average response increased the most.

In the category of teaching robotics, there was a slight increase in her average response (from 3.72 to 4.36) from pre to post classroom implementation. Most notably, Diana answered with the same or a higher number for all statements except for one in this category; the exception was for the statement "I know how to teach the programming aspects of robotics" in which she selected a lower number (from 3 to 2). This response seems consistent with Diana's attitude throughout the 
duration of the curriculum. For example, she described in her initial interview that "I'm really concerned about how to get the software working." Additionally, in one of her blog entries, she expressed that "programming continues to be challenging."

In the category of confidence in technology self-efficacy, Diana's average response increased from an average of 3.68 to 4.05 . The questions in this category addressed her self-perceived ability to use technology, help students with technological issues, assess technological projects, and future uses of technology. On all but three statements on her post-survey, Diana answered "(4) Agree" or "(5) Strongly Agree." The statements in which she selected a (3) Neither Agree/Disagree or lower asked about her confidence in assessing technology projects.

These findings may suggest a relationship between Diana's knowledge of the robotics parts and her confidence in teaching robotics. Therefore, this may be an indicator of success in the second criteria for this study.

\section{Discussion}

This paper aims to develop and evaluate a new approach that integrates robotics, engineering, and the Montessori principles by documenting the experience of one early childhood teacher. After examining Diana's responses on her surveys, interview, and blogs, the approach can be analyzed by looking at the extent to which the LEGO ${ }^{\circledR} \mathrm{WeDo}^{\mathrm{TM}}$ robotics kit promotes the principles of Montessori tangibles, Diana's comfort of integrating robotics into her classroom, and the collaboration of her students during curriculum implementation. This section will highlight the challenges and successes of Diana's Ancient Greece robotics curriculum in respect to the three criteria outlined above.

\section{Montessori Tangibles}

The LEGO ${ }^{\circledR}$ WeDo ${ }^{\mathrm{TM}}$ robotics kit has specific features that emulate the qualities of Montessori manipulatives. In particular, this kit is designed to be self-corrective, giving students the opportunity to determine if they have correctly assembled and programmed their robots without the need of adult intervention. For example, if students do not plug their robot into the computer, they can quickly realize that there is no power source and fix the problem. The Montessori principles emphasize giving students opportunities to master content independently (American Montessori Society, 2013b; Montessori, 1912). Additionally, the LEGO ${ }^{\circledR}$ WeDo ${ }^{\mathrm{TM}}$ kit appeals to different senses, including touch, sound, and sight, much in the same way as traditional Montessori manipulatives such as glass beads and knobless cylinders. Overall, the LEGO ${ }^{\circledR} \mathrm{WeDo}^{\mathrm{TM}}$ robotics kit seems consistent with the criteria expressed in the American Montessori's (2013a) most recent position statement on technology. Although this robotic kit was designed for children 8 and up and, therefore, is not developmentally appropriate for younger children, a skillful teacher such as Diana was able to adapt it for her needs.

\section{Comfort Integrating Robotics}

One of the most important criteria for successfully implementing a robotics curriculum is the teacher's comfort and confidence with the robotics materials. After just two months of teaching robotics in her classroom, Diana indicated an increase in her understanding of the parts and function of the robot, her attitude and approach to teaching, and her confidence in teaching with robotics. This falls in line with prior work demonstrating that one of the major impediments early childhood teachers face when trying to implement new technology curricula is their lack of knowledge about how the technology materials function (Bers, 2008; Bers et al., 2013). Diana's post survey responses suggest that by teaching with robotics in the classroom, she was able to increase not only her knowledge of robotics but her confidence in teaching it. This provides pre- 
liminary evidence that simply teaching with new tools may be an effective way to gain knowledge and confidence, perhaps even more so than teacher trainings or professional development.

Diana expressed that her participation in a professional development institute prior to beginning her curriculum still left her with a lack of confidence and knowledge regarding teaching with LEGO ${ }^{\circledR} \mathrm{WeDo}^{\mathrm{TM}}$. One of the biggest challenges that Diana indicated in both post-surveys and throughout curriculum implementation was her confidence in programming the LEGO ${ }^{\circledR} \mathrm{WeDo}^{\mathrm{TM}}$ robot. Seen in her response to the surveys as well as her blog, she expressed that "programming isn't intuitive." This could be due to the fact that this was Diana's first exposure to robotics in the classroom or to the fact that she found the LEGO ${ }^{\circledR} \mathrm{WeDo}^{\mathrm{TM}}$ software difficult to use. While she had previously taught the topics of simple machines and Ancient Greece many times, she had never designed a technology-focused curriculum to cover this content area. Diana expressed this frustration in one of her blog posts: "I think it's funny that I poured so much time into learning programming only to find out that 5 students in our class have already taken robotics." Despite this challenge, she said that the experience forced her "out of [her] comfort zone" and taught her new ways to integrate technology in her classroom. Evaluating this criterion demonstrates that Diana was able to dramatically increase her confidence and comfort with the robotics content by teaching it in her classroom.

\section{Student Collaboration}

Another reason that robotics was successful in Diana's classroom may be due to the very environment that she fosters using the Montessori philosophy. First, the classroom is strength-based rather than age-based in order to help children's natural tendencies unfold, and Diana was used to taking this into consideration when forming groups (Montessori, 1912). In this case, she spread out the students who had experience with $\mathrm{LEGO}{ }^{\circledR} \mathrm{WeDo}^{\mathrm{TM}}$ and those who may be stronger leaders amongst the groups to guide and help the other students. As she expressed in her curriculum post-survey, "because the classroom is already set up for students to show what they know and help others in the process, students took pride in demonstrating their skills." Diana consistently discussed how her students were at many different levels and could help one another to understand the new content area of robotics.

Diana's students frequently worked in groups because much of the Montessori approach focuses on fostering community (Montessori, 1912). Diana's students were accustomed to listening to new ideas and seeing different approaches to the same task. Diana commented on how students worked together in her class by saying, "they're used to seeing each other's strengths and working together with that in mind. So they're very respectful." The collaborative nature of Diana's Montessori approach falls in line with prior research that has demonstrated how robotic manipulatives can engage young children in collaboration and teamwork (Bers, 2008; K. Lee et al., 2013). While group work with robotics and programming manipulatives can be challenging in other classroom environments, this was not the case in Diana's Montessori classroom. One of the defining features of the Montessori approach is the close relationship between fellow students and their teacher that forms when students stay in their respective classrooms for multiple years (American Montessori Society, 2013b; Lillard, 2010). This allows close-knit collaborative communities to develop, such as the one Diana describes. Considering Diana's experience as a whole, the amount of collaboration observed in her classroom aligns well with the third criteria of this study.

\section{Additional Considerations}

In addition to the outlined criteria, qualitative data demonstrated other benefits of teaching robotics in a Montessori classroom. In particular, Diana was able to adapt her curriculum to meet the needs and expertise of her students. While Diana created a comprehensive curriculum based on 
what she had learned at the summer institute regarding robotics and engineering concepts, she adjusted the pace and content of her curriculum. For example, she had planned to teach about repeats and sensors, but did not end up using those concepts in her curriculum. As she expressed in her initial interview, "so much of what we do is follow the child or follow the lead of the class... I am trying to plan as much but leave room for flexibility and that's kind of hard. You have to be confident that it's going to work. I see the curriculum as a work in progress." Diana was able to teach the core robotic and engineering principles to her students but at an appropriate pace for them.

Furthermore, Diana's students were already familiar with using the same materials to come up with multiple solutions to the same problem. This is a fundamental engineering concept that seems to be similar to the Montessori principles. Having students understand that there is not always one correct outcome or solution to a problem made sharing and discussing each other's projects more productive. Diana explains:

They're used to - when they do projects - seeing everybody has a different outcome. They're used to seeing 'oh this is what you got this is what I got.' They're used to seeing people have the same materials but come up with different things.

This anecdote reinforces the idea of the Engineering Design Process and that there are many different ways to achieve the same goal while using the same materials (Massachusetts Department of Education, 2006).

\section{Limitations and Future Directions}

The case study presented in this paper discusses an experience of incorporating robotics in an early education Montessori classroom. Because this is a case study and only one teacher's experience implementing a $\mathrm{LEGO}{ }^{\circledR} \mathrm{WeDo}^{\mathrm{TM}}$ robotics curriculum is discussed, it is not representative of all early education Montessori classrooms. While surveys and Diana's reflections can provide an explanation regarding how robotics may enhance a Montessori classroom, more teacher experiences are needed to draw a larger conclusion.

Additionally, although anecdotal data shows that children enjoyed and learn robotics, no learning data from Diana's students was collected so it is not possible to measure how students benefited from the implementation of a robotics curriculum. In future studies, it would be worthwhile to assess students' learning of both the robotics content and the Ancient Greece/simple machine content. Furthermore, interviewing students may provide a richer understanding of how students see robotics fitting into their Montessori classroom. Finally, the LEGO ${ }^{\circledR} \mathrm{WeDo}^{\mathrm{TM}}$ software was designed for use with children ages 8 through 11. Given that Diana's students were 5 to 8 years old, the software may have been much more difficult for the students. Since the time that Diana implemented this curriculum, a variety of new developmentally-appropriate robotics kits for young children have become commercially available. For example, the new KIBO robotics kit, first developed as the KIWI prototype at Tufts University, allows children to program using wooden blocks, rather than a computer screen, and is specifically designed for children in pre-K through second grade (Bers et al., 2013). Given these developments, Diana may choose to look at the variety of new kits that best meet the needs of her students.

\section{Conclusion}

The results of this case study suggest that an effective robotics curriculum in a Montessori classroom should include materials that emulate traditional Montessori tangibles, a teacher who is comfortable and confident with teaching robotics, and a collaborative student environment. Using these criteria to evaluate Diana's experience teaching robotics, it was determined that robotics integrated well into the Montessori philosophy and her classroom culture. For Diana, integrating 
robotics into her classroom routines did not require her to take time away from teaching her standard history curriculum on Ancient Greece. Instead, she used robotics as another entry point for her students to explore the content. Because Montessori prizes personal exploration and reaching a goal from whatever path makes sense for each child, robotics offers a unique way for children to wrestle with new ideas in a way that makes sense for them (Montessori, 1912). Traditionally, subjects such as Ancient Greece are explored through reading books, having class discussions, doing math problems, and seeing visual representations. Robotics may be another way for children to experience and understand content such as Ancient Greece because it gives them the opportunity to create moving structures.

At the time that Maria Montessori cultivated her approach to education, digital technologies such as robotics did not exist. As technology becomes increasingly important in our society, robotics may be a new way of teaching content in classrooms. Diana valued mixing traditional Montessori principles with contemporary technology to teach about Ancient Greece. She demonstrated that robotics can be used as a tool that allows children to tackle new materials. Although robotics is a relatively new in early childhood education, this work suggests that an approach that emphasizes manipulatives, teacher comfort, and student collaboration could be applied in other Montessori classrooms.

\section{References}

American Montessori Society (2013a). AMS position statement on information technology. Retrieved from: http://www.tjleone.com/ams technology_position_statement.pdf

American Montessori Society (2013b). Montessori education. Retrieved from https://amshq.org/Montessori-Education

Barr, V., \& Stephenson, C. (2011). Bringing computational thinking to K-12: what is Involved and what is the role of the computer science education community? ACM Inroads, 2(1), 48-54. International Society for Technology Education and the Computer Science Teachers Association.

Barron, B., Cayton-Hodges, G., Bofferding, L., Copple, C., Darling-Hammond, L., \& Levine, M. (2011).Take a giant step: A blueprint for teaching children in a digital age. New York: The Joan Ganz Cooney Center at Sesame Workshop.

Bers, M. U. (2008). Blocks to robots: Learning with technology in the early childhood classroom. NY, NY: Teachers College Press.

Bers, M.U. (2010). Beyond computer literacy: Supporting youth's positive development through technology. New Directions for Youth Development, 128, 13 - 23.

Bers, M. U. (2012). Designing digital experiences for positive youth development: From playpen to playground. Cary, NC: Oxford.

Bers, M. U. \& Horn, M. (2010). Tangible programming in early childhood: Revisiting developmental assumptions through new technologies. In I. R. Berson \& M. J.Berson (Eds.), High-tech tots: Childhood in a digital world (pp. 49-70). Greenwich, CT: Information Age Publishing.

Bers, M. U., Flannery, L. P., Kazakoff, E. R, \& Sullivan, A. (2014). Computational thinking and tinkering: Exploration of an early childhood robotics curriculum. Computers \& Education, 72, 145-157.

Bers, M. U., Ponte I., Juelich, K., Viera, A., \&Schenker, J. (2002). Teachers as designers: Integrating robotics into early childhood education. Information Technology in Childhood Education, 1, 123-145.

Bers, M. U., Seddighin, S., \& Sullivan, A. (2013). Ready for robotics: Bringing together the T and E of STEM in early childhood teacher education. Journal of Technology and Teacher Education, 21(3), 355-377. 
Cejka, E., Rogers, C., \& Portsmore, M. (2006). Kindergarten robotics: Using robotics to motivate math, science, and engineering literacy in elementary school. International Journal of Engineering Education, 22(4), 711-722.

Cunha, F., \& Heckman, J. (2007). The technology of skill formation (No. w12840). National Bureau of Economic Research.

Gelman, R., \& Brenneman, K. (2004). Science learning pathways for young children. Early Childhood Research Quarterly, 19(1), 150-158.

Glenberg, A. M., Gutierrez, T., Levin, J. R., Japuntich, S., \& Kaschak, M. P. (2004). Activity and imagined activity can enhance young children's reading comprehension. Journal of Educational Psychology, 96, 424-436.

International Society for Technology in Education. (2007). NETS for students 2007 profiles. Washington, DC: ISTE. Retrieved from www.iste.org/standards/nets-for-students/nets-for-students-2007profiles.aspx\#PK-2

Kazakoff, E., \& Bers, M. U. (2012). Programming in a robotics context in the kindergarten classroom: The impact on sequencing skills. Journal of Educational Multimedia and Hypermedia, 21(4), 371-391.

Kazakoff, E., Sullivan, A., \& Bers, M. U. (2013). The effect of a classroom-based intensive robotics and programming workshop on sequencing ability in early childhood. Early Childhood Education Journal, 41(4), 245-255. doi:10.1007/s10643-012-0554-5

Lee, I., Martin, F., Denner, J., Coulter, B., \& Allan, W., Erickson, K.,...\&Werner, L. (2011). Computational thinking for youth in practice. ACM Inroads, 2(1), 32-37.

Lee, K., Sullivan, A., \& Bers, M. U. (2013). Collaboration by design: Using robotics to foster social interaction in Kindergarten. Computers in the Schools, 30(3), 271-281.

Lillard, A. (2010). Montessori and playful learning. American Journal of Play, 2(2), 157-186.

Madill, H., Campbell, R. G., Cullen, D. M., Armour, M. A., Einsiedel, A. A., Ciccocioppo, A. L....Coffin, W. L. (2007). Developing career commitment in STEM-related fields: Myth versus reality. In R. J. Burke, M. C. Mattis, \& E. Elgar (Eds.), Women and minorities in science, technology, engineering and mathematics: Upping the numbers (pp. 210 - 244). Northampton MA: Edward Elgar Publishing.

Markert, L. R. (1996). Gender related to success in science and technology. The Journal of Technology Studies, 22(2), 21-29.

Massachusetts Department of Education. (2006). Massachusetts science and technology/engineering curriculum framework. Retrieved from. Massachusetts Department of Education http://www.doe.mass.edu/frameworks/scitech/1006.pdf

Metz, S. S. (2007). Attracting the engineering of 2020 today. In R. Burke \& M. Mattis (Eds.), Women and minorities in science, technology, engineering and mathematics: Upping the numbers (pp. 184-209). Northampton, MA: Edward Elgar Publishing.

Montie, J. E., Xiang, Z., \& Schweinhart, L. J. (2006). Preschool experience in 10 countries: Cognitive and language performance at age 7. Early Childhood Research Quarterly, 21(3), 313-331.

Montessori, M. (1912). The Montessori Method. New York: Frederick Stokes Co.

National Association for the Education of Young Children (NAEYC) \& Fred Rogers Center for Early Learning and Children's Media. (2012).Technology and interactive media as tools in early childhood programs serving children from birth through age 8. Joint position statement. Washington, DC: NAEYC. Latrobe, PA: Fred Rogers Center for Early Learning at Saint Vincent College. Retrieved from www.naeyc.org/files/naeyc/file/positions/PS technology_WEB2.pdf

Perlman, R. (1976). Using computer technology to provide a creative learning environment for preschool children. Logo memo no 24, Cambridge, MA: MIT Artificial Intelligence Laboratory Publications. 
Reynolds, A. J., Temple, J. A., Ou, S. R., Arteaga, I. A., \& White, B. A. B. (2011). School-based early childhood education and age 28 well-being: Effects by timing, dosage, and subgroups. Science, 333(6040), 360-364.

Resnick, M., Martin, F., Berg, R., Borovoy, R., Colella, V., \& Kramer, K. et al. (1998). Digital manipulatives: New toys to think with. M. E. Atwood, C. Karat, A. Lund, J. Coutaz, \& J. Karat, Conference Editors. In SIGCHI conference on human factors in computing systems, New York: ACM Press.

Schmidt, D. A., Baran, E., Thompson, A. D., Mishra, P., Koehler, M. J., \& Shin, T. S. (2009). Technological pedagogical content knowledge (TPCK): The development and validation of an assessment instrument for preservice teachers. Journal of Research on Technology in Education, 42(2), 27.

Sesame Workshop. (2009). Sesame workshop and the PNC Foundation joint White House effort on STEM education. Retrieved from http://www.sesameworkshop.org/newsandevents/pressreleases/stemeducation_11212009

Schneider, C. (2012). 5 Characteristics connecting Montessori ed \& the digital learning movement. Learning, Online \& Blended. Retrieved from http://gettingsmart.com/2012/05/5-characteristics-connectingmontessori-ed-the-digital-learning-movement

Steele, C. M. (1997). A threat in the air: How stereotypes shape intellectual identity and performance. American Psychologist, 52(6), 613-629.

Sullivan, A., Kazakoff, E. R., \& Bers, M. U. (2013). The wheels on the bot go round and round: Robotics curriculum in pre-kindergarten. Journal of Information Technology Education: Innovations in Practice, 12, 203-219. Retrieved from http://www.jite.org/documents/Vol12/JITEv12IIPp203219Sullivan1257.pdf

Sullivan, F. R. \& Moriarty, M. A. (2009). Robotics and discovery learning: Pedagogical beliefs, teacher practice, and technology integration. Journal of Technology and Teacher Education, 17(1), 109-142. Chesapeake, VA: AACE.

U.S. Department of Education, Office of Educational Technology. (2010).Transforming American education: Learning powered by technology. Washington, DC: U.S. Department of Education, Office of Educational Technology. Retrieved from http://www.ed.gov/technology/netp-2010

Wing, J. M. (2006). Computational thinking. Communications of the ACM, 49(3), 33-35.

Zelazo, P. D., Carter, A., Reznick, J. S., \& Frye, D. (1997). Early development of executive function: A problem-solving framework. Review of General Psychology, 1(2), 198.

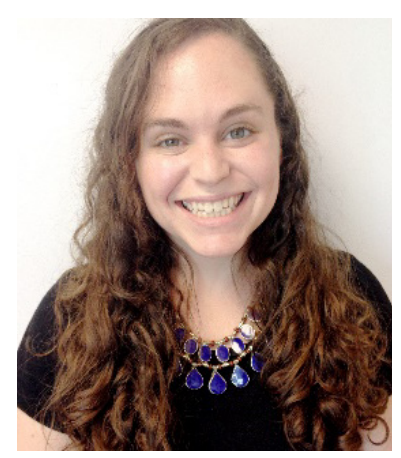

\section{Biographies}

Mollie Elkin is a Master's student at the Eliot-Pearson Department of Child Study and Human Development at Tufts University. She also completed her undergraduate degree at Tufts University in May 2014. She has been working with the DevTech Research Group for four years on a variety of projects including teaching robotics and programming to pre-kindergarten through second grade students. Mollie is passionate about how technology can enhance the learning of children with disabilities. 


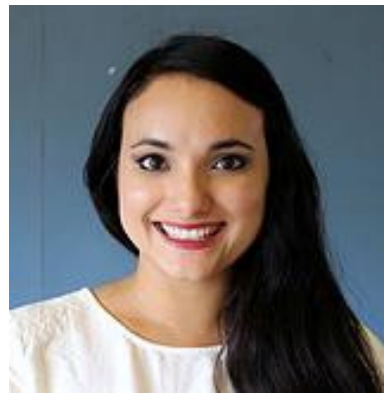

Amanda Sullivan is a doctoral student working with the DevTech Research Group in the Eliot-Pearson Department of Child Study \& Human Development at Tufts University. She holds a B.A. in Psychology and an M.A. in Child Development. Amanda's research interests broadly examine the role of new technologies and media in the lives of children. Her dissertation work looks at gender differences in young children's experiences with robotics and their emerging attitudes towards engineering and technology.

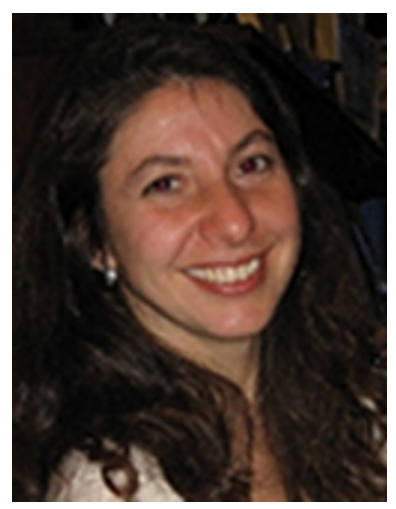

Marina Umaschi Bers is a professor at the Eliot-Pearson Department of Child Study and Human Development and the Computer Science Department at Tufts University. She heads the interdisciplinary Developmental Technologies research group which focuses on designing and studying innovative learning technologies to promote positive youth development. Dr. Bers received prestigious awards and has written two books "Blocks to Robots: Learning with Technology in the Early Childhood Classroom"(2008; Teacher's College Press) and "Designing Digital Experiences for Positive Youth Development: From Playpen to Playground" (2012; Oxford University Press). Dr. Bers has an M Ed from Boston University and an MS and PhD from the MIT Media Lab. More on Dr. Bers: http://www.tufts.edu/ mbers01/. 